\title{
THIRD GENERATION BIODIESEL: A POTENTIAL SUSTAINABLE ENERGY SOURCE FROM MICROALGAE
}

\author{
Sheetal Gadhiya ${ }^{1}$ \\ Department of Botany, \\ Bioinformatics and Climate Change Impacts \\ Management, \\ Gujarat University, \\ Ahmedabad, \\ Gujarat, 380009, \\ India.
}

\author{
Anjali Shukla ${ }^{2}$ \\ Research Scholar at Department of Botany, \\ Bioinformatics and Climate Change Impacts \\ Management, \\ Gujarat University, Ahmedabad, \\ Gujarat, 380009, \\ India
}

\author{
Nainesh Modi ${ }^{3}{ }^{3}$ \\ Associate professor at Department of Botany, \\ Bioinformatics and Climate Change Impacts Management, \\ Gujarat University, \\ Ahmedabad, Gujarat, 380009, \\ India \\ *Corresponding Author
}

Article DOI: https://doi.org/10.36713/epra4435

\begin{abstract}
Biofuel production from renewable sources is generally considered to be one of the most sustainable alternatives to fossil fuels, and a viable means of sustainability for the environment and the economy. Because of their rapid growth rate, $\mathrm{CO}_{2}$ fixation ability and high lipid production efficiency, microalgae are currently being promoted as an ideal third generation biofuel feedstock; they also do not compete with food or feed crops, and can be grown on non-arable soil. Biofuels can be generated in combination with flue gas $\mathrm{CO}_{2}$ mitigation, wastewater treatment and high value production. Seawater can be used to achieve microalgal farming employing microalgal organisms as the source. To be a realistic option, a biofuel must have few features such as net energy gain, eco-friendly, economically efficient and implementable in large volumes without affecting resources demand. In this study we present an overview of the use of microalgae for the production of biodiesel, including its cultivation, harvesting, and processing. Further it is suggested that biodiesel is an effective renewable substitute for petroleum diesel.
\end{abstract}

KEYWORDS: Biodiesel, Biofuels, Carbon emission, Microalgae

\section{INTRODUCTION}

Microalgae are microscopic unicellular organisms able to convert solar energy into chemical energy through photosynthesis. ${ }^{[1]}$ sustainable renewable energy development is hotly debated globally as it is increasing recognized that biofuels derived mainly from food crops and mostly oil seeds are restricted in their ability to achieve biofuel production targets, mitigation of climate change, and economic growth. Commercial biodiesel is made from animal fat, vegetable oil and frying oil [2] Microalgae theoretically provide the greatest long-term opportunity. [3] Some species of microalgae can accumulate up to 50-70 percent of oil / lipid by dry weight under acceptable 
crop conditions. ${ }^{[4]}$ Alternative to microalgae biofuels have been caught up by their cost and high energy output. ${ }^{[5]}$ Algae are also grown for live aquaculture feeds in hundreds of system around the world that produce from a few kilos to a maximum of a few tons of biomass per year and are often used in these small- scale, enclosed farming systems PBRS(photo bio reactor).[6] Spirulina, Chlorella, Dunaliella and Haematococcus are the major algae currently grown photosynthetically (i.e. with sunlight) for nutritional products.[6] In 2003, the global production of biodiesel was estimated at around 1.8 billion liters. ${ }^{[7]}$

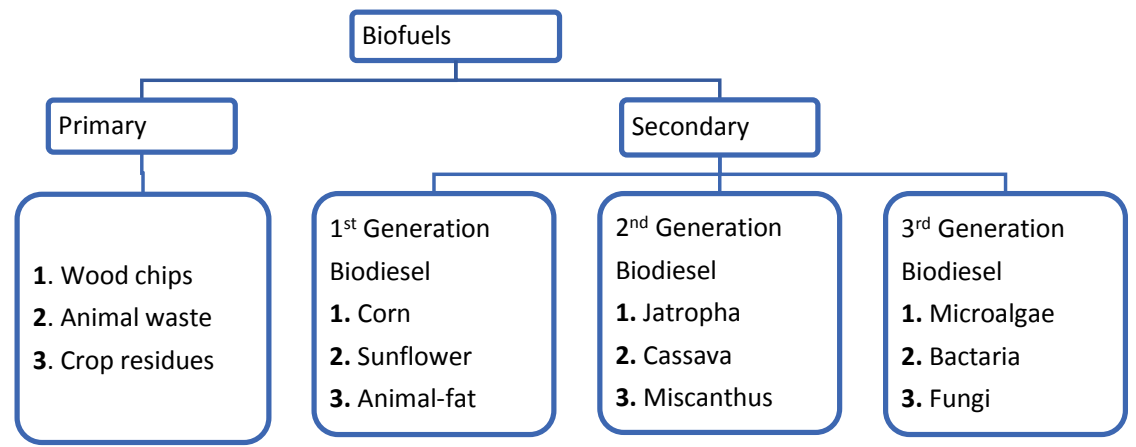

Figure 1: Biofuels classification according to various generation [18]

\section{MICROALGAE AS RAW MATERIAL FOR BIODIESEL AND BIOETHANOL PRODUCTION}

Recent studies have shown that microalgal biomass is of sustainable biodiesel's most promising source capable of meeting global demand for fuels. Microalgae based biodiesel production will not compromise food, fodder and other crop-based products. ${ }^{[4]}$ Microalgal biomass contains three main components: proteins, carbohydrates, and lipids (oil). ${ }^{[9]}$ The biomass composition of various microalgae in terms of lipid content shown in (figure 2).

Much of the on-going research work is focused on a small number of fast-growing microalgal species which have been found to accumulate substantial quantities of lipids, Though under specific conditions. Within the green algae, typical species include
Chlamydomonas reinhardtii, Dunaliella salina, and various Chlorella species, as well as Botryococcus braunii, which although slow growing can accumulate large quantities of lipids. ${ }^{[1]}$ While many microalgae strains naturally have high lipid content, it is possible to increase that concentration by optimising growth determining factors such as the control of nitrogen level, light intensity, temperature, salinity, $\mathrm{CO}_{2}$ concentration and harvesting procedure.[12] Lipid accumulation refers to increased concentration of lipids within the microalgae cells without consideration of the overall biomass production. Lipid productivity takes into account both the lipid concentration within cells and the biomass produced by these cells and is therefore a more useful indicator of the potential costs of liquid biofuel production. ${ }^{[13]}$ 


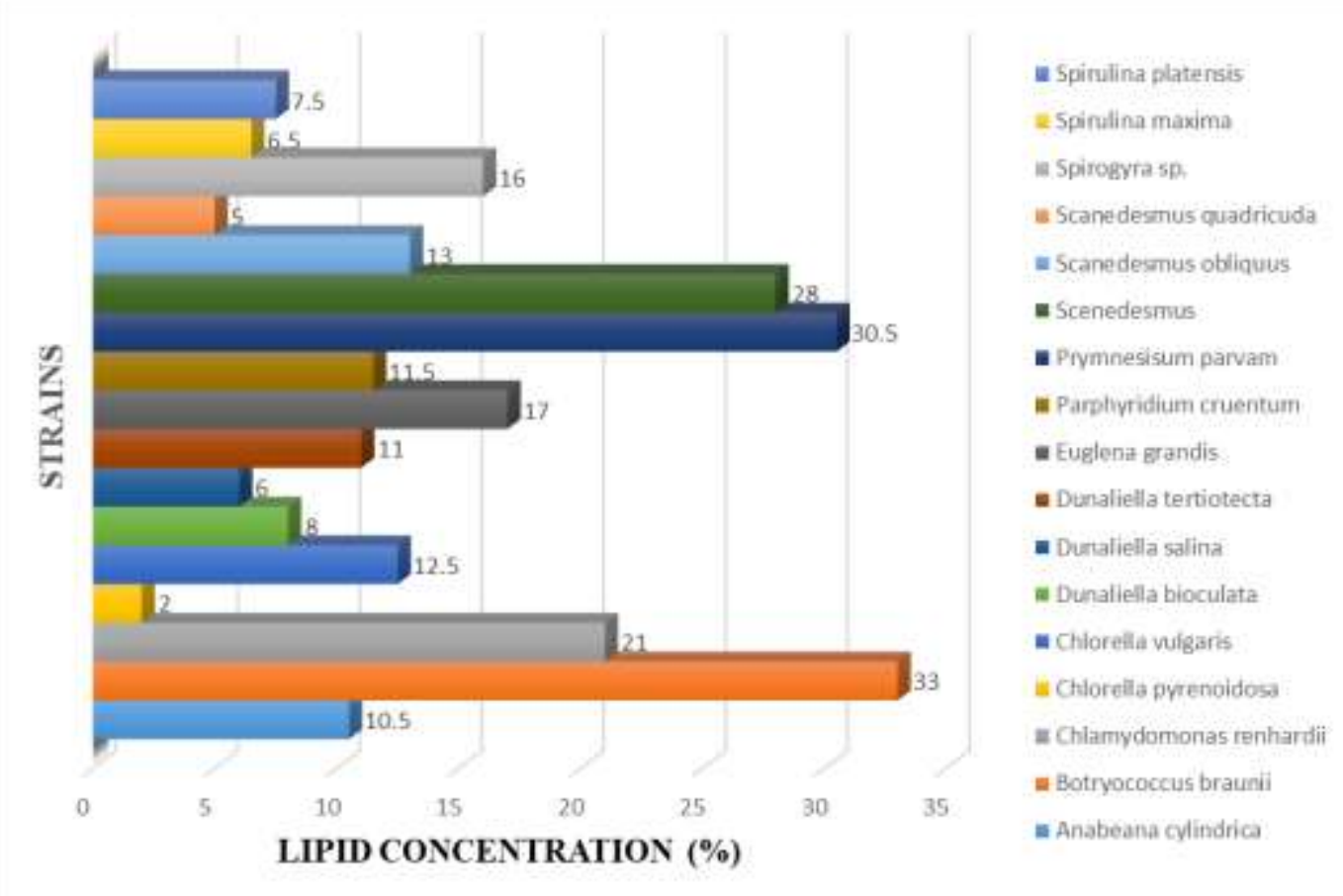

Figure 2: Lipid composition of microalgae expressed on a dry matter basis $[9,10]$

\section{METHOD OF BIODIESEL PRODUCTION}

An integrated production of biofuels from microalgae shown in (Figure 3) includes a micro algal cultivation step followed by the separation of the cells from the growth medium and subsequent lipid extraction for biodiesel production through transesterification. ${ }^{[12]}$

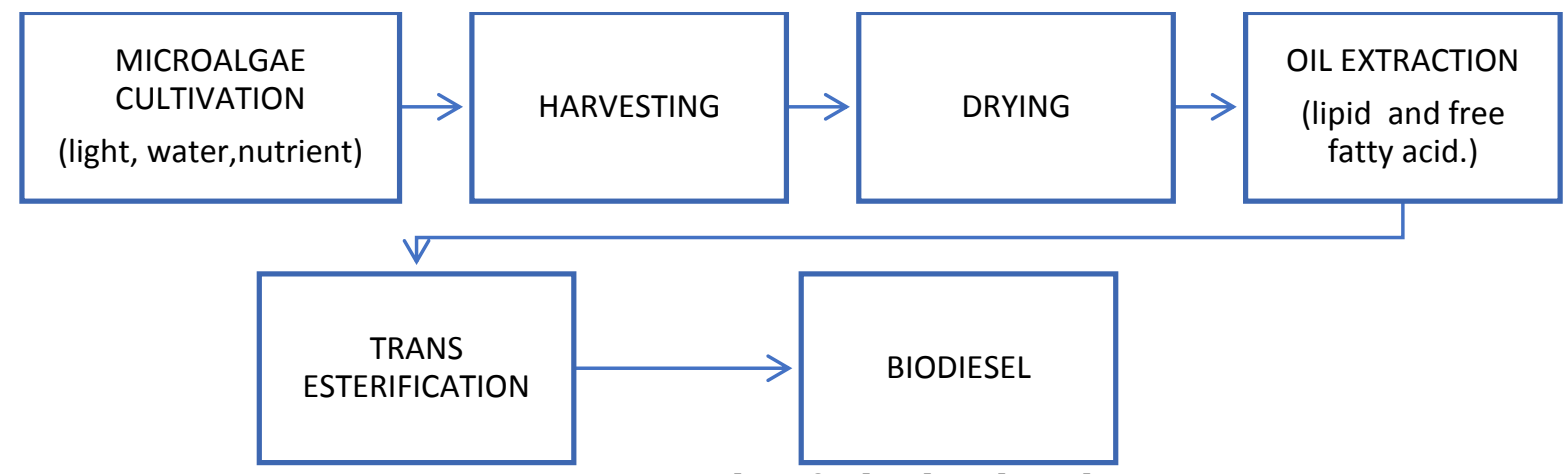

Figure 3: Step-wise procedure for biodiesel production

Why are algae used to generate bio-fuels?

a. The yield of biofuels varies geographically, wi th regions with favorable productivities offerin g optimal growth conditions. ${ }^{[12]}$

b. Algae is best suited because with an estimated 0.3 to 2.7 percent it needs significantly lower ground. While the use of soybeans will require $73 \%$ of the world's land area to meet global demand of oil.[14]

c. Nonfood-based feedstock resources. d. Use of otherwise nonproductive, nonarable land.

e. Use of a wide range of sources of water (fresh, brackish, salty, coastal. wastewater).

f. Production of useful co-products and biofuels.

g. It extends engine life and reduces maintenance requirements becausebiodiesel has better lubricating properties than fossil diesel.[15] 
h. It is safer to handle, being less toxic, more biodegradable, and having a higher flash point. ${ }^{[15]}$

i. It reduces some exhaust emissions. ${ }^{[15]}$

\section{SUSTAINABILITY OF $3^{\text {rd }}$ GENERATION ALGAL BIOFUELS}

No greenhouse gas production and reduced $\mathrm{CO}_{2}$ emissions are the key potential of Algal biofuel, which absorbs, tolerates and uses significantly higher levels of $\mathrm{CO}_{2}$ than terrestrial plants and can therefore use $\mathrm{CO}_{2}$ from petroleum power plants or other industrial sources. ${ }^{[8]}$ Both algal biomass or algal oil extracts can be processed into different types of fuel, such as biogas, liquid and gaseous transport fuel, kerosene, ethanol, aviation fuel and biohydrogen, using processing technologies such as anaerobic digestion, pyrolysis, gasification, catalytic cracking and chemical transesterification enzymes. ${ }^{[16]}$ Apparently much of the carbon capture and sequestration (CCS) debates are about geological storage of $\mathrm{CO}_{2}$. Only by removing carbon from the atmosphere may we reduce carbon capture by reducing the release of new fossil reserves. ${ }^{[17]}$ As microalgae grow in aqueous conditions, the direct passage of fuel gasses through this medium is a very efficient way to capture $\mathrm{CO}_{2}$ in those streams.[18] The application of $\mathrm{CO}_{2}$ directly to terrestrial crops by enclosures is likely to be prohibitively costly, while indirect stimulation of terrestrial species through fuel gasses is an alternative method that can be costeffective despite being much less direct and less productive. ${ }^{[17]}$ A green colonial microalga, A green colonial microalga, the Botryococcus braunii is an exceptionally rich renewable source of hydrocarbons. In a study harvested wet microalgae, thermally pretreated with a solvent extraction cycle to improve hydrocarbon recovery. ${ }^{[19]}$ Samples which contain a B mixture. Braunii and water were held for 10 minutes under $100^{\circ} \mathrm{C}$. At $90^{\circ} \mathrm{C}$, the hydrocarbon recovery observed was 97.8 per cent. The real global output of oil from oilseed crops in 2007-2008 was 0.592 t ha1 for that year. ${ }^{[20]}$ Algal biofuels production seems very promising, efficient and sustainable as they can be generated from industrial wastewater and fuel gases. In addition, it sequesters large quantities of $\mathrm{CO}_{2}$ with less land use than terrestrial crops. This is why many assume these microalgae is the only economic route to biodiesel. ${ }^{[21,22]}$ The major factors influencing the effect of biofuels include their contribution to land-use transition, the feedstock used and technology and scale issues. Biofuels provide economic benefits, and can reduce pollution and make a significant contribution to energy security under the right circumstances. Development of the various biofuels has its own benefits, complexities and dangers. ${ }^{[23]}$

\section{CURRENT ALTERNATIVE FOR MICRO ALGAE PRODUCTION OF TECHNICAL FEEDSTOCK}

Microalgae production is limited to small factories in the current decade; worldwide only around 6000 tons of distillate water are extracted autotrophically each year. The key benefits of open ponds are their smoother construction and operation compared with other structures. ${ }^{[20]}$ The open ponds are therefore ideal for microalgae processing in hybrid processes along with wastewater treatment. The closed or artificial ponds (circular ponds and raceway ponds) are effective in the production of microalgae where regulation of the processing environment is much better than that of the open ponds or large ponds. ${ }^{[20]}$ In addition, some wastewater treatment facilities also use raceway ponds along with microalgae output for water treatment. PBRS (photo bioreactors) are ideally suited for the development of selective strain-specific algal biomass to increase lipid productivity ( $\mathrm{mg} / \mathrm{L} /$ day) and biofuel productivity (daily). PBRS methods are more effective in terms of productivity $\left(\mathrm{kg} / \mathrm{m}^{3} / \mathrm{d}\right)$, concentration of biomass $\left(\mathrm{kg} / \mathrm{m}^{3}\right)$, and yield of oil $\left(\mathrm{m}^{3} / \mathrm{ha}\right)$ than raceway production methods. ${ }^{[4]}$ Other advantages of photobioreactors include temperature control, improved gas transfer control $\left(\mathrm{CO}_{2}\right)$ and protection from climate-related impacts such as drought, evaporation, and diurnal and seasonal variations in temperature. ${ }^{[3]}$ PBRS needs less land than open pond systems, so there are no variations in light intensity when PBRS is positioned horizontally compared to open pond. ${ }^{[19]}$ The efficiency of vertically oriented PBRS is around half that of horizontally oriented PBRS, due to the decreased light availability. Air, $\mathrm{CO}_{2}$, nutrient, and sunlight are the key contributors to increasing microalgae. Microalgae can be cheap and efficient in desert saltwater ponds and PBRS adjusted at a consistent temperature. [12] The use of $\mathrm{CO}_{2}$ in PBRS is much more effective than in open ponds, where $\mathrm{CO}_{2}$ can escape into the atmosphere. The PBRS 'biggest downside is the handling of $\mathrm{O}_{2}$ and it involves degassing stations from $\mathrm{O}_{2}$. The horizontal tubular PBRS is therefore effective and useful for the substantial production of specific microalgae for biofuel production. ${ }^{[12]}$

\section{CONCLUSION}

Microalgae deliver high potential, third generation, biofuels such as biodiesel and bioethanol as a sustainable raw material. Technical advancements, particularly developments in the design of photo bioreactors, microalgal biomass extraction, drying and handling become key fields which can improve costeffectiveness and thus successful commercial application of biofuels. Current challenges are the use 
of lignocellulosic biomass (2nd generation biofuels), which is available abundantly, by thermal or enzymatic methods. Hopes are placed on $3^{\text {rd }}$ generation biofuels which is energetic compounds obtained from microorganisms like algae or cyanobacteria from sunlight. These technologies have not yet reached commercial maturity, and metabolic engineering can support research efforts.

\section{Conflict of Interest}

The authors declare that they have no competing interest.

\section{Acknowledgement}

The writers express their thankfulness to the authorities of Gujarat University, India.

\section{REFERENCES}

1. Milledge, J. J., \& Heaven, S. (2013). A review of the harvesting of micro-algae for biofuel production. Reviews in Environmental Science and Bio/Technology, 12(2), 165-178.

2. Barnwal. B. K., \& Sharma, M. P. (2005). Prospects of biodiesel production from vegetable oils in India. Renewable and sustainable energy reviews, 9(4), 363-378.

3. Mata, T. M., Martins, A. A., \& Caetano, N. S. (2010). Microalgae for biodiesel production and other applications: a review. Renewable and sustainable energy reviews, 14(1), 217-232.

4. Chisti, Y. (2007). Biodiesel from microalgae. Biotechnology advances, 25(3), 294-306.

5. Teixeira, C. M. L. L., Kirsten, F. V., \& Teixeira, P. C. N. (2012). Evaluation of Moringa oleifera seed flour as a flocculating agent for potential biodiesel producer microalgae. Journal of applied Phycology, 24(3), 557563.

6. Benemann, J. R. (2009). Microalgae biofuels: a brief introduction. Benemann Associates and MicroBio Engineering, Walnut Creek, $C A$.

7. Fulton L.(2004) Biomass and agriculture sustainability, markets and policies. International Energy Agency (IEA) biofuels study-interim report: result and key messages so far. IEA, France, OECD Publication Service; $p$. 105-12.

8. Nigam P, Singh A. Production of liquid biofuels from renewable resources. Prog Energy Combust Sci 2011;37:52-68.

9. Um B-H, Kim Y-S. Review: A chance for Korea to advance algal-biodiesel technology. Journal of Industrial and EngineeringChemistry. 2009; 15:1-7.

10. Sydney, E. B., Sturm, W., de Carvalho, J. C., ThomazSoccol, V., Larroche, C., Pandey, A., \&Soccol, C. R. (2010). Potential carbon dioxide fixation by industrially important microalgae. Bioresource technology, 101(15), 5892-5896

11. Scott, S. A., Davey, M. P., Dennis, J. S., Horst, I., Howe, C. J., Lea-Smith, D. J., \& Smith, A. G. (2010). Biodiesel from algae: challenges and prospects. Current opinion in biotechnology, 21(3), 277-286.

12. Dragone, G., Fernandes, B. D., Vicente, A. A., \& Teixeira, J. A. (2010). Third generation biofuels from microalgae.

13. Brennan, L., \&Owende, P. (2010). Biofuels from microalgae - a review of technologies for production, processing, and extractions of biofuels and coproducts. Renewable and sustainable energy reviews, 14(2), 557-577.

14. Ullah F, Dong L, Bano A, Peng Q, Huang J (2016) Current advances in catalysis toward sustainable biodiesel production. J Energy Inst 89:282-292.

15. Wardle, J., Cooke, L. J., Gibson, E. L., Sapochnik, M., Sheiham, A., \& Lawson, M. (2003). Increasing children's acceptance of vegetables; a randomized trial of parent-led exposure. Appetite, 40(2), 155-162.

16. Subhadra B (2010) Sustainability of algal biofuel production using integrated renewable energy park (IREP) and algal biorefinery approach. Energy Policy 38:5892-5901

17. Scragg, A. H., Illman, A. M., Carden, A., \& Shales, S. W. (2002). Growth of microalgae with increased calorific values in a tubular bioreactor. Biomass and Bioenergy, 23(1), 67-73.

18. Li, Y., \& Horsman, M. (2008). Wu,. N.; Lan, CQ; Dubois_calero, N. Biofuels from algae. Biotechnol. Prog, 24, 815-820.

19. Pedroni, P. M., Lamenti, G., Prosperi, G., Ritorto, L., Scolla, G., Capuano, F., \&Valdiserri, M. (2005). Enitecnologie $R \& D$ project on microalgae biofixation of CO2: outdoor comparative tests of biomass productivity using flue gas CO2 from a NGCC power plant. In Greenhouse Gas Control Technologies 7 (pp. 10371042). Elsevier Science Ltd.

20. Benemann, J. R. (2009). Microalgae biofuels: a brief introduction. Benemann Associates and MicroBio Engineering, Walnut Creek, CA.

21. Ho, S. H., Chen, C. Y., Lee, D. J., \& Chang, J. S. (2011). Perspectives on microalgal CO2-emission mitigation systems - a review. Biotechnology advances, 29(2), 189198.

22. Carvalho, A. P., Meireles, L. A., \& Malcata, F. X. (2006). Microalgal reactors: a review of enclosed system designs and performances. Biotechnology progress, 22(6), 1490-1506.

23. Maity, J. P., Bundschuh, J., Chen, C. Y., \& Bhattacharya, P. (2014). Microalgae for third generation biofuel production, mitigation of greenhouse gas emissions and wastewater treatment: Present and future perspectives-A mini review. Energy, 78, 104-113 


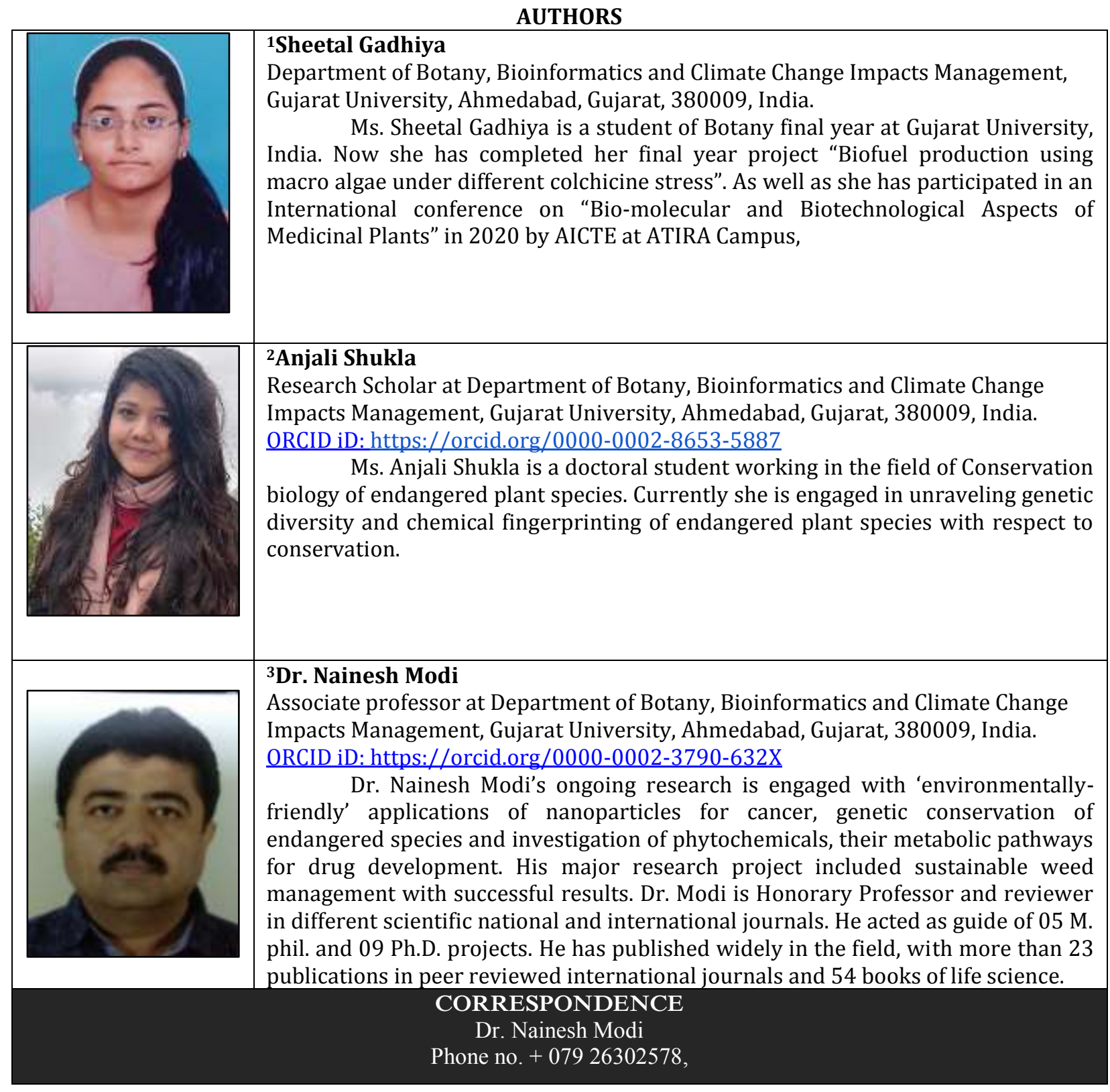

